\title{
What kind of commons are the urban commons?
}

\author{
Susana Narotzky
}

Optimism of the will permeates this article, which builds on Lefebvre's idea of The Right to the City ([1968] 2009) and its more recent revival by Harvey, specially in his last work where, after a period of scepticism regarding recent urban social movements as potentially politically transformative, he seems to vindicate their potential as part of a class understanding of these movements (2012).

Starting by reminding us about social movements around the world in the post-2007 period, two main arguments are made: First, that cities are "transformative forces." Second, that the three-dimensional "right to the city" that Lefebvre proposed (everyday life, sharing space, and creative activity) is enacted through the creation and/or reclaiming of three forms of "commons": urban commons around production and consumption (the claim to public goods and services and a "decent everyday life"), urban commons around public spaces of mobility and encounter, and urban commons around creativity and collective visions designing imagined communities. The hypothesis presented is that "when brought together, these three urban commons set the conditions for a renewed right to the city in all the dimensions elaborated by Lefebvre and, we argue, set the stage for social movements."

Although this is an exciting prospect, I want to argue that we need a stronger analytical argument in order to embrace this proposition as more than an optimistic prediction. The main issue that needs elaboration is how/why the concept of "urban commons" is accurate and/or useful for explaining the contemporary social movements and their political economic transformative relevance. Lefebvre constituted the urban as the form (the concrete abstraction) of the reproduction of social relations of production in late capitalism. The production of space in its contemporary urban form expressed the contradictions of present-day capitalism: the increased centrality of power versus the increased segregation of the powerless to the peripheries, the technical homogenization of space versus its commercial fragmentation. Space, then, becomes the element that envelops other forms of differentiation that sustain the social reproduction of capitalism. It becomes the key to the transformation of social relations of production. This transformation needs the collective production, management, and appropriation of space (Lefebvre [1972] 2000). There are not many concrete examples in Lefebvre's writing on what this process entails. Harvey (2012) takes the issue of the commons in a much more accurate perspective and his book tries to evaluate the implications and complexities of the "urban commons" concept quite thoroughly from a theoretical perspective.

The present article could have used detailed ethnographic accounts of the actual practices in the recent urban social mobilizations and public space settlements in order to foreground the practice of "commoning" (ibid.: 73). In my un- 
derstanding, this means: what commons are being defined as resources, which communities of people are being designed as holding rights to them, how are regulations developed, what modes of enforcement are set in place? Because commons are about resources and how they are appropriated in particular social relations that contribute to reproducing or, instead, to transforming existing social relations of production, the concept should not be treated lightly or overextended in such a way that it becomes a vague metaphor. The reference to scholarship on so-called traditional commons is pretty scant and no reference is made to the considerable anthropological literature on the subject. As a result, the selected definition of the concept feels superficial and possibly misleading: "common property is an individual's right not to be excluded from the uses or benefits of resources" (Blackmar 2006). Compare this to the classical anthropological definition (Feeny et al. 1990; see also Ostrom et al. 1999) that defines common property regimes as one where "property is held by an identifiable community of interdependent users. Users exclude outsiders while regulating use by members of the local community" (Feeny et al. 1990: 5). This "common" system is clearly different from "open access" (what Hardin misinterpreted as commons), where access is free and open to everyone and unregulated. As has been extensively demonstrated in the literature, exclusion and regulation are two central aspects of the commons. Unfortunately, in this article we have no way to know how the boundaries and the rules are organized and what kinds of tensions these processes produce in the case of urban commons. Sometimes there almost seems to be confusion between open access and communal access.

Moreover, the authors follow Harvey's idea that "a common shall be both collective and non-commodified-off limits to the logic of market exchange and market valuations" (2012: 73). While this is a very commendable political project, in the historical and ethnographic literature "the logic of market exchange and market valuations" is often entangled in complex ways with the commons, as is the logic of state man- agement (McCay and Acheson 1987; Acheson 1989; Arguedas 1987). In most cases, a plurality of regimes of appropriation coexist, often overlap, and produce particular forms of commons, particular social relations of production, and particular conflicts. Historically, modes of appropriation and regulation often shift or express disjuncture between de jure norms and de facto practices. So "real existing commons", from which the theoretical concept derives, are complex processes that are not quite exempt of struggle.

So, to get back to the article, what does claiming or producing (public) urban spaces as "commons" around production and consumption, around mobility and encounter, and around creativity mean? Do the commons stand for a reconfigured and better form of "public good"? And if so, what social relations do they help to produce and reproduce over time? What are, empirically, the observable processes of "commoning" and what boundaries, exclusions, and regulations produce urban space as an equitably accessed resource? What kinds of entanglements with local, political, and administrative institutions such as regional or municipal governments are created in these processes? ${ }^{1}$

Using the commons and its inevitable corollary, the community, as a theoretical concept for explaining present-day urban social movements against capitalism becomes problematic if the concept is not used in a rigorous manner. It therefore ought to be based on thorough ethnographic analyses. It is a concept that has often been used in slippery ways in politics, with many different and often contradictory messages. This article fails to provide sufficient analytic ethnographic specificity about the actual processes of producing these "commons" through collective mobilization in the urban space.

Susana Narotzky is a professor of anthropology at the University of Barcelona. Her main focus has been on the anthropology of work, with particular attention to unregulated production and care practices within and across genera- 
tions. She has recently published "Europe in Crisis: Grassroots Economies and the Anthropological Turn," 2012, Etnográfica 16(3): 627638; "Alternatives to Expanded Accumulation and the Anthropological Imagination: Turning Necessity into a Challenge to Capitalism?" in Confronting Capital: Critique and Engagement in Anthropology, 2012, London: Routledge; and "Memories of Conflict and Present-day Struggles in Europe: New Tensions between Corporatism, Class, and Social Movements," 2011, Identities 18(2): 97-112.

narotzky@ub.edu.

\section{Notes}

1. We should remember that the French Paris Commune of 1871, which is often used as a referent of the urban commons, refers to municipal autonomy as well as to a different form of access, production, and distribution of resources (Rougerie [1971] 2004).

\section{References}

Acheson, James 1989. Management of commonproperty resources. In Stuart Plattner, ed., Eco- nomic anthropology, pp. 351-378. Palo Alto, CA: Stanford University Press.

Arguedas, José María 1987. Las comunidades de España y del Perú. Madrid: Ministerio de Agricultura, Pesca y Alimentación.

Blackmar, Elizabeth. 2006. Appropriating "the commons": The tragedy of property right discourse. In Setha Low and Neil Smith, eds., The politics of public space, pp. 49-80. New York: Routledge.

Feeny, David, Fikret Berkes, Bonnie McCay, and James Acheson. 1990. The tragedy of the commons: Twenty-two years latter. Human Ecology 18(1): 1-19.

Harvey, David. 2012. Rebel cities: From the right to the city to the urban revolution. London: Verso.

Lefebvre, Henri. [1972] 2000. Espace et politique. Paris: Anthropos.

Lefebvre, Henri. [1968] 2009. Le droit à la ville, Paris: Economica/Anthropos.

McCay, Bonnie, and James Acheson. 1987. The question of the commons: The culture and ecology of communal resources. Tucson: University of Arizona Press.

Rougerie, Jacques. [1971] 2004. Paris libre 1871. Paris: Seuil.

Ostrom, Elinor, Joanna Burger, Christopher B. Field, Richard B. Norgaard, and David Policansky. 1999. Revisiting the commons: Local lessons, global challenges. Science 284: 278-282. 